\title{
REKONSTRUKSI TEMATIK ATAS KONSEP NABI DAN MISI KENABIAN DALAM ALQURAN
}

\author{
Muh. Fathoni Hasyim \\ Universitas Islam Negeri Sunan Ampel Surabaya \\ info@uinsby.ac.id
}

\begin{abstract}
One of the very basic idea of the Qur'an is on the humanity of the prophet as like other creatures. Every single person has their own creative potency (in potentia) which, according to some philosophers, enables them to reach the degree of prophecy. This idea has then made a prophecy to come to a mundane term which has not to do with any sacred property. Prophets and prophecy are then not considered as an essential thing in human history. This notion has clearly put aside the role and function of prophet in human life. There is also popular opinion in the society that the prophet is considered as God's chosen people to receive revelation, but, at some degree, they are conceived as having no responsibility to proselytize people under God's revelation. This notion, beside to releases the prophet's role from his social responsibility, contains some logical fallacies. If guiding people to the right path is being an individual's responsibility of the follower of monotheist religion, how it is possible, then, to remove the responsibility of the prophets toward their society. Therefore, this study aims to revisiting the concept of prophecy, and analyzing the prophetic mission in terms of thematic interpretation.
\end{abstract}

Key Words: Prophet, Apostle, Social Responsibility, Thematic Interpretation.

Abstrak: Salah satu pandangan mendasar dalam Alquran adalah bahwa Nabi merupakan manusia biasa. Dalam diri manusia terdapat potensi kreatif (in potentia) yang, menurut beberapa filosof, memungkinkan mereka untuk mencapai level kenabian. Gagasan ini jelas memposisikan kenabian dalam terminologi duniawi yang tidak terkait sama sekali dengan sakralitas eskatologis. Dengan begitu, realitas kenabian tidak lagi dipandang sebagai sesuatu yang esensial dalam sejarah kemanusiaan. Pandangan ini jelas mereduksi fungsi dan peran nabi dalam kehidupan manusia. Sosok nabi yang dianggap sebagai pilihan Tuhan, tidak lagi memiliki sebuah privilege. Disamping itu, opini yang populer di masyarakat menganggap bahwa nabi adalah manusia pilihan Tuhan untuk menerima wahyu, namun tidak mendapat beban tanggungjawab membumikan wahyu itu pada 
umatnya. Pendapat ini, selain melepaskan nabi dari tanggungjawab sosial, juga mengandung gagasan yang kurang meyakinkan. Jika transfer of knowledge dan membimbing umat menjadi kewajiban individu setiap pengikut agama tauhid, bagaimana mungkin kewajiban itu lepas dari fungsi seorang Nabi. Oleh karena itu, artikel ini mengkaji konsep kenabian dan kerasulan, serta menganalisa misi profetik yang diembannya dalam perpektif tafsir tematik.

Kata Kunci: Nabi, Rasul, Tanggungjawab Sosial, Tafsir Tematik.

\section{Pendahuluan}

Dalam asumsi teologis, ada anggapan bahwa akal tanpa bimbingan wahyu dapat mengetahui dua ajaran fundamental agama, yaitu: mengetahui Tuhan dan mengetahui kebaikan dan keburukan. Ketika sampai pada pengetahuan akan Tuhan dan pengetahuan akan yang baik dan yang buruk, akal manusia dapat pula mengetahui kewajiban-kewajibannya terhadap Tuhan, dan kewajiban untuk berbuat baik dan menjauhi yang buruk. Pandangan ini secara diametral dapat mereduksi fungsi dan peran wahyu dalam kehidupan manusia. Pada titik tertentu, pandangan ini juga mengesampingkan peran Nabi sebagai manusia utusan yang bertugas untuk menggandeng manusia ke jalan Tuhan dan tindak kebajikan. ${ }^{1}$ Pandangan tersebut kemudian menganggap peran nabi hanyalah sekunder dan komplementer.

Kontradiksi pembedaan yang tajam antara komitmen sosial nabi dan rasul, juga menjadi salah satu penyebab yang mengaburkan misi dan peran nabi. Opini yang telah mapan menganggap bahwa nabi adalah orang yang dipilih Tuhan untuk menerima wahyu, tetapi tidak mendapat beban tanggungjawab untuk membumikan wahyu kepada alam semesta. Pendapat ini jelas melepaskan nabi dari tanggungjawab sosial. Nabi tidak mempunyai kewajiban memandu dan membimbing umat menuju kebenaran dan kebaikan. Tanggungjawab sosial diletakkan sepenuhnya pada pundak rasul. Karena rasul dipandang sebagai manusia utusan Tuhan yang mendapat wahyu dan berkewajiban untuk menyampaikan (tabligh) kepada manusia. Pendapat ini pada dasarnya juga semakin mengaburkan misi dan peran nabi sebagai insan terpilih yang menerima wahyu. Jika demikian,

\footnotetext{
${ }^{1}$ Abdurrahman Badawi, Sejarah Ateis Islam, Penyelewengan, Penyimpangan, Kemapanan, terj. Khoiron Nahdiyyin (Yogyakarta: Lkis, 2003), 112.
} 
apa nilai dan fungsi dari wahyu itu sendiri bagi kepentingan sosial manakala hanya diletakkan dalam dimensi individu?

Penggunaan terminologi nabi dan rasul juga sering dipertukarkan, seakan tidak ada beda antara keduanya. Barangkali itu terjadi karena adanya beberapa nabi yang didapuk sekaligus sebagai rasul. ${ }^{2}$ Apabila kita berpijak pada opini yang menganggap bahwa kedudukan rasul lebih tinggi daripada nabi, ${ }^{3}$ maka menurut etika penyebutan seharusnya menggunakan sebutan yang lebih tinggi, yaitu 25 rasul bukan 25 nabi. ${ }^{4}$ Alquran sendiri menggunakan dua kata tersebut secara bergantian terhadap 25 nabi dan rasul. Lihat misalnya dalam QS. al-Nisā' [4]: 163-165, QS. al-Mu'min [40]: 78, QS. al-Aḥzāb [32]: 40, Alquran terkadang menyebut seseorang sebagai nabi, terkadang juga menyebutnya sebagai rasul, dan di ayat lain, Alquran menyebutnya secara bersama-sama. Apakah hal ini menunjukkan antara nabi dan rasul tidak berbeda, baik secara substansial maupun secara fungsional?

Beberapa paradoks inilah yang akan dikaji dalam artikel ini. Tulisan ini bertujuan untuk mengetengahkan kembali konsep nabi dan rasul yang dalam Alquran dengan menggunakan metode tafsir tematik.

\section{Terminologi Nabi dan Rasul}

Kata nabi secara etimologis berasal dari kata naba', yang artinya warta (news), berita (tidings), cerita (story), dan dongeng (tale). Dalam Alquran, kata nabi (jamaknya nabiyyūn atau anbiyā), berasal dari satu akar kata yang sama yaitu naba', bersama beberapa kata yang lain seperti nubuwwah (prophethood atau kenabian), nabba'a dan anba'a (to tell atau bercerita) dan istanba'a (meminta untuk diceritakan). Menurut Imām Sibawayh, hamzah dalam kata nabi dibuang, karena

\footnotetext{
${ }^{2}$ Dalam pandangan Muktazilah, tidak ada beda antara nabi dan rasul. Setiap nabi adalah rasul dan setiap rasul adalah nabi. Muhammad Fakhruddin b. Dịäa al-Dīn 'Umar al-Rāzi, Tafsìir al-Fakhr Al-Rǟi al-Mushtahar bi al-Tafsìr al-Kabì wa Mafätị alGhayb, vol. 23 (Beirut: Dār al-Fikr, 2005), 236.

${ }^{3}$ Al-Ṣabūni melihat bahwa martabat kerasulan lebih tinggi daripada kenabian, dengan argumen bahwa setiap rasul pasti nabi, tetapi tidak untuk sebaliknya. Muḥammad 'Ali al-Ṣābūni, Al-Nubuwwah wa al-Anbiya's' (Damaskus: Mu'assasat alGhazā̄i, 1985), 13.

${ }^{4}$ Alquran mengajarkan etika penyebutan, bahwa ketika kata rasul disebut bersamasama dengan kata nabi dalam satu ayat, maka kata rasul disebut lebih dulu, kemudian kata nabi disebut setelahnya. Lihat misalnya, QS. al-Haji [22]: 52.
} 
penggunaan hamzah dalam kata nabi dipandang oleh orang Arab (selain penduduk Mekkah) sebagai inferior language, oleh karena itu jarang dipakai. Dalam sebuah riwayat, nabi sendiri menunjukkan sikap tidak suka pada penggunaan hamzah pada kata nabi: Ketika datang seorang laki-laki dengan menyebut "yā nabi'ullah", Nabi menjawab jangan kau mengolok-olokkan namaku, sesungguhnya aku adalah "nabiyyulläh" (tanpa hamzah). Bahkan menurut al-Farrā, bacaan nabi yang mujma' "alayh (disepakati) adalah dengan membuang hamzah. Dalam bahasa Inggris, kata nabi biasa disebut dengan prophet, yang berarti seseorang yang mengajarkan agama, dan mengklaim mendapat inspirasi ataupun petunjuk dari Tuhan dan prophetess sebutan untuk nabi perempuan. ${ }^{6}$

Secara terminologis, kata nabi memiliki banyak definisi. Menurut al-Farrā', nabi adalah seseorang yang menerima wahyu dari Allah melalui ilham atau mimpi yang benar. ${ }^{7}$ Menurut pendapat yang popular, Nabi adalah orang yang mendapat wahyu dari Allah yang berisikan syariat, tanpa diperintahkan menyampaikan wahyu itu kepada umatnya. ${ }^{8}$ Definisi pertama mengindikasikan bahwa proses perolehan wahyu (pengetahuan) seorang nabi hanyalah dengan cara yang sangat samar dan tersembunyi, dan tidak pernah pula diperolehnya dalam keadaaan terjaga atau sadar, tetapi diyakini bahwa wahyu itu datangnya dari Allah. Sedangkan definisi kedua, yaitu definisi yang populer, mengaburkan tugas kenabian dan komitmen

${ }^{5}$ Muhammad b. Manzur, Lisān al-'Arab al-Muhit, vol. 3 (Beirut: Dār lisān al-'Arab, t.th.), 561; Hans Wehr, A Dictionary of Modern Written Arabic (Wiesbaden: Otto Harrassowitz, 1971), 937; Muhammad Rashìd Rị̣ā, Tafsīr al-Manār, vol. 9 (Beirut: Dār al-Ma'ärif, t.t.), 225.

${ }^{6}$ A.S. Hornby, Oxford Advanced Learner's Dictionary of Current English, ed. Jonathan Crowther (Oxford: Oxford University Press, 1995), 929. Berangkat dari pengertian nabi di atas, yaitu orang yang mendapat wahyu dari Tuhan, ada yang berpendapat bahwa semua orang yang mendapat wahyu tak terkecuali beberapa tokoh wanita yang pernah mendapat wahyu juga mendapat gelar nabi, seperti Maryam Ibu Nabi 'Tsā dan juga Sarah istri Nabi Ibrāhìm karena mendapat wahyu, bahkan Malaikat pernah berbicara dengannya dalam keadaan sadar. Muhammad al-Ṭāhir b. 'Āshür, Al-Taḅrì wa al-Tanwìr, vol. 24 (Tunisia: al-Dār al-Tünisìiah li alNashr, 1984), 211.

${ }^{7}$ Abū 'Abdillāh Muhammad b. Aḥmad al-Anșāiri al-Qurțubi, Al-jāmi' li Abkām alQur'ān, ed. 'Abdullāh b. 'Abd al-Muhsin al-Turki, vol. 12 (Beirut: al-Risālah, 2006), 80.

${ }^{8}$ Muhammad Quraish Shihab, Tafsir al-Mishbah, vol. 2 (Jakarta: Lentera Hati, 2012), 813. Al-Rāzi, Mafätih, vol 23, 236. 
sosialnya, karena nabi tidak dituntut menyampaikan misi yang diembannya untuk konteks sosial.

Kata nabi dan bentuk-bentuk pluralnya disebut dalam Alquran sebanyak 75 kali dalam 20 surat, 57 ayat di antaranya diturunkan di Madinah, 18 ayat sisanya diturunkan di Mekkah. Sedangkan kata naba' sendiri disebut 29 kali dalam 21 surat. Dari sekian ayat yang membicarakan nabi di atas, yang paling representatif untuk bahasan ini antara lain: QS. al-Kahfi [18]: 110, QS. Maryam [19]: 30, QS. alFurqān [25]: 7, QS. al-Nisā' [4]: 163, QS. al-Aḩzāb [33]: 45, QS. alMa'idah [5]: 44 dan QS. al-Tawbah [9]: 73.

Pembahasan tentang term nabi (al-nabi, prophet) dan kenabian (alnubunwah, prophecy) tidak terlepas dari term rasul (al-rasul, apostle) dan kerasulan (al-risälah, apostolic), pengutusan (consignment). Kata rasul secara etimologis berarti kurir atau utusan (messenger, emissary, envoy, delegate, apostle). Kata rasul memiliki bentuk plural rusul, ${ }^{9}$ meski demikian kata rasul juga sering dipakai untuk makna jamak, seperti dalam QS. alTawbah [9]: 128 dan QS. al-Shu'arā' [26]: 16. Alquran sering menyebut para utusan dengan al-mursalin, yaitu "mereka yang diutus".

Kata rasul dengan segala bentuknya (singular, double maupun plural) dalam Alquran disebut sebanyak 333 kali. Dengan rincian, bentuk mufrad (singular) sebanyak 235 kali, bentuk double (tathniyah) hanya 1 (satu) kali, dan dalam bentuk plural (jamak) 97 kali. Kata rasül dalam bentuk tunggal nakirah disebut sebanyak 59 kali, dan disertai alif lam (makrifat) al-rasül disebut sebanyak 58 kali dan bentuk tunggal yang di-idafah-kan disebut sebanyak 118 kali. ${ }^{10}$ Kata rasul mempunyai makna yang lebih luas daripada nabi. Nabi tidak ada yang bearasal dari selain manusia, sedangkan rasul ada yang berasal dari selain manusia, yaitu malaikat, QS. al-Fātir [35], QS. al-An`àm [6]: 61 dan QS. al-A'rāaf [7]: 37.

Secara terminologis, kata rasul berarti orang yang mendapatkan wahyu dari Allah melalui perantara malaikat Jibril, dalam keadaan terjaga dan sadar. ${ }^{11}$ Atau menurut pendapat yang popular, bahwa rasul adalah orang mendapatkan wahyu dari Allah yang berisi syariat dan

${ }^{9}$ Hans Wehr, A Dictionary of Modern Written Arabic, 338. Lihat juga, Ahmad Warson Munawwir, Kamus al-Munawwir (Yogyakarta: PP. Al-Munawwir, 1984), 532.

${ }^{10}$ Muhammad Fu'ād 'Abd al-Bāqi, Al-Mu'jam al-Mufahras li al-Alfä al-Qur'an al-Karim (Beirut:: Dār al-Fikr, 1987), 312-320.

11 Al-Qurtubīi, Al-Jāmi', vol. 6, 17. 
berkewajiban menyampaikan kepada umatnya. ${ }^{12}$ Definisi rasul yang pertama menunjukan adanya proses penerimaan wahyu yang lebih meyakinkan. Wahyu diterima dalam kondisi terjaga dan sadar, bahkan terkadang mengadakan dialog dengan malaikat pembawa wahyu. Definisi kedua menunjukkan komitmen sosial rasul sebagai orang terpilih dalam membumikan wahyu yang diterimanya. Sehingga menjadi kewajiban bagi seorang rasul untuk menyampaikan dan mencerahkan, memandu dan membimbing umatnya pada akidah yang benar, dan kehidupan yang sejahtera serta mendapat rida-Nya.

Dalam pandangan para Filosof, nabi maupun rasul adalah manusia biasa, sebagaimana lainnya. Setiap manusia memiliki potensi kreatif (malakah) yang ada di dalam internal dirinya. Dengan potensi kreatif itu manusia bisa menemukan pengetahuan tentang Tuhan, kebaikan dan keburukan, serta kebahagiaan dan penderitaan. Dengan demikian, setiap orang mempunyai peluang menjadi nabi, karena mereka memiliki potensi kreatif yang sama seperti para nabi. Oleh karena itu kenabian dalam realitasnya merupakan sesuatu yang wajar, bukan sesuatu yang istimewa. ${ }^{13}$ Wahyu merupakan bentuk komunikasi Tuhan dengan manusia. Jika setiap manusia mempunyai potensi internal untuk berkomunikasi dengan Tuhan, maka pembahasan masalah nabi dan kenabian menjadi tidak terlalu penting, mereduksi peran dan tanggung jawab nabi sebagai manusia pilihan.

Sementara itu, para mufasir melihat bahwa nabi dan rasul adalah manusia pilihan. Kenabian dipahami sebagai peristiwa murni karunia ilahi. Kenabian tidak dapat diperoleh melalui usaha, memperbanyak ibadah dan olah batin, dan bukan pula merupakan warisan yang bisa diperoleh secara turun temurun. Pandangan ini berusaha memposisikan nabi sebagai golongan manusia istimewa, pilihan Tuhan. Manusia yang sanggup menerima beban berat yang mempunyai keteguhan dan kebersihan hati. Alquran juga menggunakan term 'pilihan' untuk menunjuk kepada para nabi. Kata yang digunakan Alquran dalam memilih manusia istimewa ini menggunakan beberapa kata, seperti kata iștafá (memilih) dengan derivasinya digunakan dalam QS. al-Hajj [22]: 75 "Allah memilih utusan-utusannya dari malaikat dan dari manusia”; QS. al-Baqarah

\footnotetext{
12 Al-Ṣabūni, Al-Nubunwah, p. 13

${ }^{13}$ Munawir, "Konsep Kenabian Menurut Ibnu Khaldun Telaah Korelasi Kemaksuman dan Kemanusiaan Nabi Muhammad SAW.," dalam Jurnal Bidayah, Vol. 15, No. 1 (2014), 120-121.
} 
[2]:130 tentang pemilihan nabi Ibrahim; QS. al-A'rāf [7]: 144, tentang pemilihan Musa; QS. Āli 'Imrān [3]: 42 tentang pemilihan Maryam, dan kata ikhtära (memilih) dengan derivasinya seperti yang terdapat dalam QS. Țāhā [20]: 13 berkaitan dengan pemilihan nabi Musa sebagai rasul dan nabi; QS. al-Ṣâd [38]: 45-47 berkaitan dengan pengukuhan Ibrāhim, Ishạà dan Ya'qūb sebagai manusia pilihan. Dalam ayat ini, kedua istilah di atas digunakan secara bersama-sama dan dalam QS. al-A ‘ăf [7]: 144 berkaitan dengan pemilihan Musa sebagai rasul.

Ayat-ayat di atas secara tekstual menunjukkan bahwa kenabian dan kerasulan merupakan karunia Tuhan. Ia bukanlah sesuatu yang diusahakan, namun lebih pada sebuah takdir yang merupakan scenario pilihan Tuhan. Dari sini terlihat bahwa para Mufassir memandang baik nabi maupun rasul adalah manusia pilihan yang memiliki kapasitas lebih, sehingga mereka layak terpilih menjadi nabi dan atau rasul. Asumsi dasar dari pilihan ini barangkali berangkat dari rasionalitas bahwa tidak semua orang mampu membawa beban berat risalah kenabian dan kerasulan. Hanya mereka, yang menurut Tuhan teruji kesabaran, kejujuran dan kesalihannya yang akan dipilih oleh Tuhan menjadi utusan-Nya. Dalam titik ini kenabian dan kerasulan merupakan sebuah ketetapan yang bukan menjadi medium negosiasi. Kenabian merupakan sebuah proses natural dari sebuah skenario Tuhan atas semesta yang mengikuti ritme kehendak-Nya.

\section{Diferensiasi Simbolik Antara Nabi dan Rasul}

Dalam literatur keislaman, jumlah nabi dan rasul berkisar antara 124.000 nabi, yang di antaranya, 313 atau 315 merupakan rasul. ${ }^{14}$ Namun Alquran sendiri hanya menyebutkan:

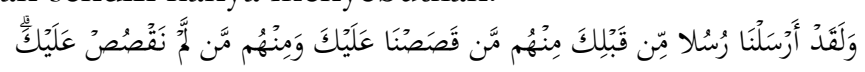

Dan sesungguhnya telah Kami utus beberapa orang rasul sebelum kamu, di antara mereka ada yang Kami ceritakan kepadamu dan di antara mereka ada (pula) yang tidak Kami ceritakan kepadamu.

QS. Ghäfir [40]: 78.

Ayat ini berbicara bahwa jumlah nabi itu memang banyak dan hanya sebagian saja yang disebut dalam Alquran. QS. Yūnus [10]: 47

\footnotetext{
${ }^{14}$ Jumlah Rasul 313 didasarkan pada hadis riwayat sahabat Abū Dharr al-Ghifari. Sedangkan yang menyebut 315 rasul, didasarkan pada hadis riwayat sahabat Abi

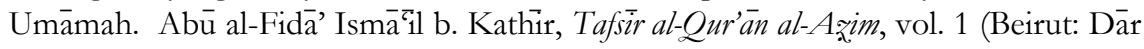
al-Fikr, 1986), 586-587.
} 
menyebutkan bahwa setiap umat pasti ada utusan. Jika jumlah umat berkisar puluhan ribu, maka logis jika jumlah nabi juga puluhan ribu, hanya pandangan ini tidak ditemukan sandaran yang kuat. Pendapat para mufasir yang menyebut jumlah nabi 124.000 dan jumlah rasul 315, didasarkan pada hadis-hadis yang kualitasnya diperselisihkan, sebagian besar ahli hadis dan mufasir menilainya sebagai hadis daif. Hadis riwayat Imām Aḥmad dari sahabat Abū Dharr al-Ghifari. Dalam hadis tersebut terdapat seorang perawi Ibrāhīm b. Hishām, yang dipandang oleh para tokoh kritikus hadis sebagai perawi yang diragukan dan dicurigai (muttaham). Dalam pandangan Abü Hạtim dan Abū Zur'ah, dia adalah seorang pembohong (kadhdhäb), dan menurut al-Dhahabi adalah perawi yang ditinggalkan (matruk). Bahkan Ibn alJawzi mengelompokkan hadis tersebut dalam kitabnya "al-Maw' dü'at", kitab yang merangkum hadis-hadis palsu.

Demikian juga hadis riwayat Ahmad dari jalur lain dan sahabat lain yaitu dari Abū Hạtim. Hadis dari jalur ini, menurut Ibn Kathir juga lemah (da if ), karena ada tiga orang perawi yang dipandang lemah, yaitu Mu'an b. Rifa'ah al-Salami, 'Alì b. Yazid dan al-Qāsim Abū 'Abd al-Raḥmān. ${ }^{15}$ Penentuan jumlah nabi dan rasul di atas tidak memberi pengetahuan yang cukup meyakinkan, karena didasarkan pada hadis-hadis yang daif. Argumen yang bisa membuahkan kepastian adalah yang didasarkan pada nas Alquran atau hadis yang sahih.

Dalam ayat di atas juga disebutkan bahwa sebagian nabi diceritakan dan sebagian yang lain tidak diceritakan. Pertanyaannya mengapa tidak diceritakan semua, sehingga dapat memperluas wawasan dalam mengambil itibär? Para mufassir berpendapat bahwa tidak disebutkannya semua nama nabi, karena jumlahnya yang sangat banyak. Menurut al-Suyutưi, karena mereka bukanlah nabi-nabi yang populer. Hal ini sesuai dengan prinsip Alquran sebagai kitab suci yang tidak mungkin memuat segala sesuatu secara detail. ${ }^{16}$

Sejarah para nabi dan umat yang dibimbingnya pada waktu itu, tidak semuanya diketahui oleh manusia yang hidup di jazirah Arab, baik oleh umat Islam sendiri maupun ahli kitab, seperti nabi-nabi yang

${ }^{15}$ Ibid., vol. 2, 470; Muhammad b. Hibbān al-Tamimi, Sahịh b. Hịbbān, vol. 2 (Beirut: Mu'assasat al-Risālah, 1993), 77; 'Abd al-Raḥmān Jalāl al-Dìn al-Suyūtịi, Al-Durr alManthür fì Tafsìr al-Ma'thür, vol. 2 (Beirut: Dār al-Fikr, 2011), 746.

${ }^{16}$ Kementerian Agama R.I., Tafsir Mudhu'i: Tafsir al-Qur'an Tematik, vol. 9 Jakarta: Lentera Ilmu Makrifat, 2019), 137. 
mendapat tugas membimbing umat atau bangsa-bangsa di Asia Timur seperti Cina, Jepang, India dan Thailand, atau di Afrika, Eropa dan Amerika. Sehingga mereka akan mengalami kesulitan untuk memahaminya. Sama dengan perumpamaan dalam Alquran yang hanya menyebut tumbuhan dan binatang yang diketahui oleh masyarakat di Timur Tengah, seperti korma, gandum, tin, zaitun, onta, kuda, domba dan lain-lainnya. Alquran tidak menyebut padi, mangga, kelapa, kanguru, koala atau panda karena tanaman dan binatang tersebut tidak dikenal oleh masyarakat yang hidup di Timur Tengah pada waktu itu, sehingga akan mengalami kesulitan memahaminya. Sebagaimana tujuan kisah dari Alquran adalah agar menjadi 'ibrah (pelajaran), peringatan, juga untuk meneguhkan kenabian Muhammad, ${ }^{17}$ seperti yang disingggung dalam QS. Yüsuf [12]: 111 dan QS. Hūd [11]: 120.

Alquran sebagai sumber ajaran Islam yang otoritatif, tidak secara definitif menyatakan jumlah nabi dan rasul, dan tidak secara kronologis menyebut nama nabi dan rasul sesuai dengan urutan masa kenabiannya. Dalam literature keislaman, nama-nama nabi dan rasul yang disebut secara eksplisit dalam Alquran berjumlah dua puluh lima. ${ }^{18}$ Mereka itu adalah Adam, Idriss, Nūh, Hūe, Ṣăliḥ, Ibrāhim, Lut, Ismā̄īl, Ishạàq, Ya'qūb, Yùsuf, Ayyūb, Shu'ayb, Mūsāà, Hārūn, Dhulkifl, Dāwūd, Sulaymān, Ilyās, Ilyāsa', Yūnus, Zakaryāa, Yaḥyā, 'Is̄à dan Muhammad.

Delapan belas nama rasul dan nabi di atas disebut dalam satu ayat QS. al-An'àm [6]: 83-86, sedangkan 7 (tujuh) nama lainnya yaitu Adam, Idrìis, Hūd, Shu'ayb, Șăliḥ, Dhulkifl dan Muhammad disebut secara tersebar di beberapa surat dan ayat Alquran. Diantara 25 orang nabi itu, terdapat 5 orang yang mempunyai kelebihan, yaitu ulü al-'azm, yang berarti orang yang berhati teguh dan memiliki kesabaran yang tangguh.

Di samping itu, terdapat nama-nama lain yang disebut secara implisit kenabiannya dan masih belum ada kebulatan pendapat di kalangan mufasir seperti: Hị̣̂r, Luqmān, Dhu al-Qarnayn, Shamuel,

\footnotetext{
${ }^{17}$ Aḥmad Muștafă al-Marāghi, Tafsìr al-Marāghì, vol. 6 (Beirut: Dār al-Fikr, t.t.), 22. Lihat juga, Riḍāa, Al-Manār, vol 6, 58.

${ }^{18} \mathrm{Ibn}$ al-'Āshür, Al-Taḅrìr, vol. 24, 211.
} 
'Uzayr, Shith, 'Imrān, dan Mariyam Ibunda 'Isā. ${ }^{19}$ Dalam Alquran, sekian banyak nabi, baik yang disebut namanya maupun tidak, tak satupun di antara mereka yang berasal dari makhluk selain manusia, mereka adalah manusia biasa sebagaima kita.

Uraian di atas menunjukkan bahwa nabi bukan manusia eksklusif atau manusia setengah Tuhan, tetapi ia adalah manusia biasa yang perlu makan, minum, nikah dan berkomunikasi dengan sesama manusia atau kaumnya. Bedanya hanyalah dia dipilih Tuhan untuk menerima wahyu, dan diberi tanggungjawab membumikan wahyu yang diterimanya pada umatnya, di samping berperan sebagai decision maker terhadap persoalan-persoalan yang dihadapi umatnya.

Term rasul dan nabi telah diperbincangkan para ulama dengan pendapat yang sangat beragam. Ada yang menyamakan antara keduanya dan tidak sedikit pula yang melakukan diferensiasi terhadapnya. Al-Alüsi telah merangkum pendapat-pendapat tersebut sebagai berikut: Pertama, rasul adalah seorang laki-laki merdeka, yang diutus oleh Allah dengan membawa syariat baru, berdakwah kepada manusia untuk menaati syariat baru tersebut. Sedangkan nabi lebih umum yaitu orang yang diutus untuk meneguhkan syariat yang dibawa oleh nabi sebelumnya, seperti nabi-nabi Bani Israil yang diutus antara nabi Musa sampai nabi Isa. ${ }^{20}$ Nabi-nabi Bani Israil yang dimaksud adalah nabi Dāwūd, Sulaymān, Yahyā, Zakariyā, yang semuanya bergelar nabi, bukan rasul. ${ }^{21}$ Adapun nabi-nabi bani Israil lainnya yang tidak disebutkan namanya dalam Alquran maupun sunah adalah karena mereka tidak membawa syariat baru. Mereka hanya mensosialisasikan dan mengimplementasikan syariat yang dibawa oleh Nabi Musa yang telah hadir sebelumnya.

Definisi di atas memunculkan pertanyaan, apakah kitab Zabur yang diturunkan pada Nabi Dawud tidak berisi syariat, sehingga nabi Dawud tereliminasi dari gelar rasul? Menurut al-Qurțūbi, Kitab Zabur

\footnotetext{
${ }^{19}$ Ibid. Disebutkan juga beberapa nama nabi yang belum ada kesepakatan para ulama, karena hanya didasarkan pada hadis, seperti 'Abbūd yang berkulit hitam, Hanẓalah b. Șafwan ahl Rass dan Khālid b. Sinān.

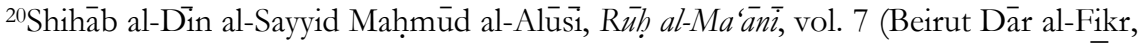
1983), 65. Nabi-nabi Bani Israil yang diutus antara Nabi Musa dengan Nabi 'Isā semuanya disebut nabi sampai datang rasul berikutnya, yaitu 'Tsā. Lihat, Ibn 'Āshūr, Al-Tạ̣rì, vol. 17, 297. Lihat juga, Nạsir al-Dīn Abū al-Khayr 'Abdullāh al-Bayḍ̄āwi, Anwār al-Tanzīl wa Asrār al-Ta'wīl, ed. Muhammad 'Abd al-Raḥmān al-Mur'ashili, vol. 4 (Beirut: Dār Ihỵā' al-Turāth, t.th.), 75.

${ }^{21}$ Kementerian Agama, Tafsir Mudhu'i, vol. 9, 125.
} 
yang diturunkan pada Nabi Dāwūd berisi 150 surat, tetapi tidak berisikan syariat baru, tidak ada muatan hokum seperti halal-haram dan hanya memuat hikmah. ${ }^{22}$ Jadi, fungsi kehadiran nabi-nabi tersebut termasuk nabi Dāwūd adalah untuk meneguhkan kembali syariat yang telah dibawa nabi Musa yang kemudian diabaikan, dilupakan, diselewengkan atau bahkan diingkari oleh umatnya.

Kedua, rasul adalah seorang laki-laki yang diutus oleh Allah pada suatu kaum dengan membawa syariat baru bagi kaumnya, meskipun bukan syariat baru bagi dirinya. Contoh dari pemaknaan ini adalah Nabi Ismā $\bar{i}$ il yang pada awal mulanya diutus pada kabilah Jurhum. ${ }^{23}$ Nabi Ismāīil diutus bersamaan waktunya dengan Nabi Ibrāhim. Syariat yang disampaikan adalah syariat yang dibawa nabi Ibrähim, tetapi obyek dakwahnya berbeda. Nabi Ismāil berdakwah pada suku Jurhum di Mekkah, sedangkan nabi Ibrahim di Palestina.

Ketiga, rasul adalah seorang laki-laki merdeka, yang menyampaikan misinya secara global, meskipun dia juga menjelaskan secara detail syariat rasul sebelumnya. Sedangkan nabi adalah orang yang mendapat wahyu, tetapi dia tidak mendapat tugas menyampaikan misi kenabiannya sama sekali. ${ }^{24}$ Pembedaan ini mengambil contoh nabi Muhammad ketika turun kepadanya wahyu pertama QS. al-'Alaq [96]: 1-5. Nabi Muhammad tidak diperintahkan untuk menyampaikan wahyu tersebut pada umatnya, meskipun terdapat argumen apologis bahwa nabi menyampaikan wahyu itu pada keluarganya, yaitu istrinya Khadijah.

Nabi Muhammad mendapat gelar rasul setelah turun kepadanya QS. al-Muddaththir [74]: 1-5. Kandungan surat al-Muddaththir adalah perintah agar Nabi Muhammad menyampaikan misi kenabian pada umatnya. Dengan perintah ini, nabi Muhammad mencapai derajat risalah atau diangkat menjadi rasul. ${ }^{25}$ Menurut al-Māwardi, kenabian itu merupakan pendahuluan dari kerasulan. ${ }^{26}$ Maka dengan turunnya

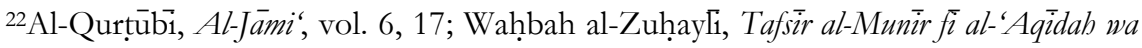
al-Shari' ah wa al-Manhaj, vol. 4 (Beirut: Dār al-Fikr al-Mu'ạșir, 1991), 34.

${ }^{23}$ Al-Alùsi, Rūḥ al-Ma'ánì, vol. 7, 65.

${ }^{24}$ Ibid.

${ }^{25}$ TM. Hasbi Ash-Shiddieqy, Sejarah dan Pengantar Ilmu al-Qur'an dan Tafsir (Semarang: Pustaka Rizki Putra, 2000), 36-37.

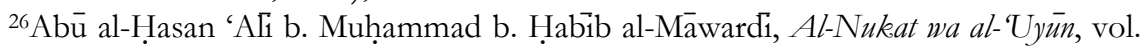
6 (Beirut: Dār al-Kutub al-'Ilmìyah, t.th.), 135.
} 
perintah untuk menyampaikan misi kenabian tersebut, nabi Muhammad naik ke derajat rasul.

Argumen tersebut ditolak karena yang dimaksud tabligh (menyampaikan) itu pada umatnya, bukan hanya keluarganya. Sedangkan peneladan yang dilakukan nabi Muhammad sudah sejak sebelum diangkat menjadi nabi. Nabi Muhammad sejak awal berakhlak mulia, perilakunya dapat dijadikan teladan oleh manusia lainnya. Di samping itu, mengabaikan tugas penyampaian berarti menyembunyikan wahyu (kitmān al-ílm). Padahal dalam pandangan ahli hadis, pengetahuan yang diperoleh melalui wahyu adalah sesuatu yang meyakinkan. Allah menurunkan wahyu untuk disebarluaskan bukan untuk disimpan dalam diri sendiri. ${ }^{27}$ Para ilmuwan secara moral berkewajiban menyampaikan ilmunya, mengajari mereka yang masih tidak tahu, memberi petunjuk pada yang tersesat, dan menjawab pertanyaan yang muncul dari masyarakat. Kalau para ilmuwan saja berkewajiban menyampaikan ilmu pengetahuan yang diketahuinya, apalagi para nabi yang menerima wahyu (pengetahuan) secara meyakinkan langsung dari Allah? Jadi, baik nabi maupun rasul mempunyai kewajiban menyampaikan wahyu yang diterima pada umatnya.

Keempat, rasul adalah bagian daripada nabi, yaitu orang yang dibekali mukjizat dan kitab yang diturunkan padanya, sedangkan nabi yang bukan rasul ialah orang yang tidak mendapatkan kitab. ${ }^{28}$ Menurut definisi ini, nabi Dāwūd termasuk rasul, karena Dāwūd dibekali mukjizat dan kitab, meskipun tidak berisi syariat.

Kelima, rasul adalah orang yang mendapatkan kitab yang menghapus (nasakh) syariat sebelumnya secara global. Sedangkan nabi adalah orang yang tidak mendapatkan kitab dan tidak menghapus syariat rasul sebelumnya. ${ }^{29}$ Pendapat ini adalah salah satu dari tiga pendapat yang membedakan nabi dengan rasul pilihan al-Rāzi, tetapi al-Rāzi menambahkan frasa 'dan diberi mukjizat'. Apabila tidak memenuhi dua kriteria ini, maka dinamakan nabi bukan rasul, seperti Ishạà, Ya'qūb, Ayyūb, Yūnus, Hārūn, Dāwūd dan Sulaymān, karena mereka tidak diberi kitab yang menghapus syariat nabi sebelumnya. ${ }^{30}$

\footnotetext{
${ }^{27}$ Eni Zulaiha, "Fenomena Nabi dan Kenabian Dalam Perspektif al-Qur'an," dalam Al-Bayan Jurnal Studi al-Qur'a dan Tafsir, vol. 1, no. 2 (2016), 149-164.

${ }^{28}$ Al-Alūsi, Rūh al-Ma'ànī, vol. 7, 65.

${ }^{29} \mathrm{Ibid}$.

${ }^{30}$ Al-Rāzi, Mafätih, vol. 13, 236.
} 
Meskipun nabi-nabi tersebut diberi mukjizat untuk membuktikan kenabiannya, atau diberi kitab seperti nabi Dawud, tetapi karena tidak membawa syariat baru, maka tidak dapat dikatagorikan sebagai rasul.

Keenam, rasul adalah orang yang menerima wahyu dengan kehadiran malaikat dalam kondisi terjaga dan sadar serta berbicara dengan malaikat, sedangkan nabi adalah orang yang mendapat wahyu dalam kondisi tidur atau via mimpi. ${ }^{31}$ Pendapat ini menurut al-Qurțūbi adalah pendapat al-Farrā', yang dikutip olehnya dengan tambahan kalimat bahwa nabi menerima wahyu melalui mimpi dan ilham. ${ }^{32}$ Karena mimpi para nabi adalah wahyu.

Pendapat yang disebut terakhir ini, menurut al-Alūsi adalah pendapat yang paling langka atau aneh, karena mencakup pengertian bahwa ada sebagian nabi yang tidak pernah mendapat wahyu kecuali dalam kondisi tidur. Namun pendapat ini justru yang dipilih oleh alRāzi sebagai pendapat yang utama. ${ }^{33}$ Penulis Tafsìr al-Mī̌án, alṬabătabāî̀, juga memilih pendapat tersebut berdasarkan riwayat dari para abl al-bayt (keluarga nabi). Ia menyanggah bahwa perbedaan nabi dengan rasul seperti disebutkan pada urutan pertama, menurut alTabătabāi adalah bahwa syariat yang dibawa oleh para nabi tidak lebih dari lima, yaitu syariat yang dibawa oleh Nūh, Ibrāhim, Mūsā,

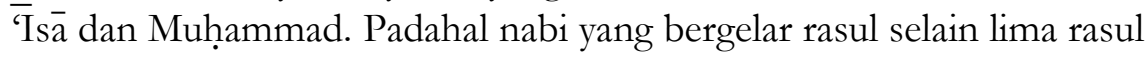
tersebut lebih banyak. Oleh karena itu perbedaan yang disebut pertama tidak berdasar. ${ }^{34}$ Namun menurut al-Rāzi, penyebutan lima nama nabi pembawa syariat, yaitu: Nūh, Muḥammad, Ibrāhīm, Mūsā dan 'Tsā dalam QS. al-Shūrā [42]: 13, karena mereka merupakan pembesar para nabi yang memiliki jumlah pengikut cukup besar. ${ }^{35}$

Perbedaan antara nabi dengan rasul yang dikemukakan para ulama, masing-masing mempunyai argumen yang kuat, namun selalu ada kelebihan dan kekurangannya. Ada tiga kriteria nabi dan rasul yang hampir disepakati oleh jumhur ulama. Pertama, baik nabi maupun rasul adalah manusia yang dipilih untuk menerima dan menyampaikan wahyu pada umatnya. Kedua, semua rasul pasti nabi, namun tidak semua nabi adalah rasul. Dengan kata lain bahwa nabi lebih umum

\footnotetext{
${ }^{31}$ Al-Alùsi, Rūḥ al-Ma'ánì, vol. 7, 65.

${ }^{32} \mathrm{Al}-\mathrm{Qurtūbi}$, Al-Jämi', vol. 12, 17.

${ }^{33} \mathrm{Al}-\mathrm{R} a \bar{z} \bar{i}$, Mafatih, vol. 13, 236.

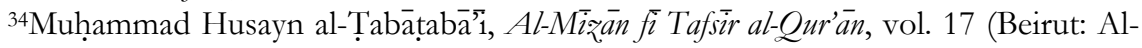

'Alami Library. t.th.), 391-392.

${ }^{35}$ Al-Rāzi, Mafatih, vol. 13, 422.
} 
daripada rasul, tidak sebaliknya. Ketiga, hirarki kerasulan lebih tinggi daripada kenabian, meskipun penyebutannya sering dipertukarkan. Sedangkan definisi yang membedakan antara nabi dengan rasul yang lebih representatif adalah menggabungkan antara definisi yang berorientasi pada konten wahyu yang dibawanya dengan obyek wahyu atau umat yang menjadi sasaran dakwahnya.

Nabi dan rasul adalah orang yang dimuliakan Allah, karena mereka adalah manusia pilihan. Yang membedakan antara keduanya adalah materi wahyu yang diterimanya. Wahyu yang diterima rasul adalah berupa syariat baru, sedangkan wahyu yang diterima nabi adalah peneguhan atas syariat yang telah ada. Nabi Adam termasuk pada katagori rasul, karena membawa syariat yang betul-betul baru, seperti syariat perkawinan dengan sistem silang antara dua saudara kembar. Demikian juga dengan perintah berkorban dengan binatang ternak atau hasil bumi, seperti yang tersurat dalam QS. al-Mà-idah [5]: 27.

Di samping materi wahyu, obyek wahyu atau sasaran dakwah para nabi juga menjadi symbol pembeda antara keduanya. Apabila obyeknya adalah orang-orang kafir dan musyrik, maka berstatus rasul, tetapi kalau obyeknya orang-orang yang beriman yang lalai atau mengabaikan ajaran atau syariat yang pernah diajarkan oleh rasul sebelumnya, maka statusnya adalah nabi. Oleh karena itu, Nūh, Ismāīil, Lü dan nabi-nabi lainnya yang diutus dakwah pada obyek tersebut berstatus rasul, karena obyek yang dihadapi adalah orang kafir dan musyrik.

\section{Syariat Kenabian dan Kerasulan}

Materi wahyu yang membedakan antara nabi dengan rasul adalah syariat yang diterimanya. Apabila muatan wahyu yang diterimanya baru, maka dia disebut rasul, namun apabila muatan wahyu hanya meneguhkan syariat yang dibawa oleh rasul sebelumnya, maka disebut nabi. Statemen di atas memunculkan sejumlah pertanyaan, apakah yang dimaksud dengan syariat tersebut? Apakah syariat sama dengan agama? Apakah agama yang dibawa oleh para nabi semuanya sama?

Agama dalam pandangan Maḥmūd Shaltụt terdiri dari 2 (dua) unsur utama, yaitu akidah dan syariah. ${ }^{36}$ Akidah adalah keyakinan atau keimanan yang harus dimiliki oleh setiap orang, terutama

${ }^{36}$ Maḥmūd Shaltūt, Al-Islam 'Aqìidah wa Sharì'ah (Mesir: Dār al-Qalam, 1966), 11-12. 
keyakinan terhadap keesaan Allah. Risalah kenabian dan kerasulan yang disampaikan oleh para nabi dan rasul, semuanya sama, tidak ada perbedaan, yaitu mengesakan Allah. Jadi tidak ada seorang nabi atau rasul yang mengajarkan politeisme. Rashid Rida menyebutkan bahwa agama yang diajarkan oleh para nabi, sejak Adam hingga Muhammad hanya satu, yaitu agama tauhid dan Allah tidak menerima selain agama tauhid. ${ }^{37}$ Agama dalam bahasa Arabnya disebut al-Din pada masa-masa awal sering digunakan untuk menyebut term akidah. Para Mufassir menyebut kesamaan agama yang dibawa para nabi hanyalah dalam konteks mengesakan Allah, karena keesaan Allah itulah ajaran paling fundamental dari agama.

Akidah dalam konteks kekinian adalah keimanan secara menyeluruh, yaitu iman kepada Allah, malaikat, rasul, kitab, hari kiamat, serta qada dan qadar, baik dan buruknya dari Allah semata. Sedangkan syariah adalah sekumpulan hukum syariat yang mengatur seluruh masalah manusia. ${ }^{38}$ Dengan kata lain, Allah memberikan misi pada semua utusannya untuk menyampaikan ajaran tauhid yang sama. Sedangkan ajaran berupa syariat, dalam pengertian aturan tentang tingkah laku manusia, akan berkembang secara evolotif hingga mencapai kesempurnaan pada syariat Muhammad. ${ }^{39}$ Jadi, agama (al-din) berbeda dengan syariat. Syariat merupakan bagian dari agama, demikian juga akidah.

Syariat juga merupakan salah satu unsur utama dari agama, karena agama merupakan kesatuan aturan yang terdiri dari akidah dan syariah. Pertanyaannya kemudian adalah apakah syariat yang dibawa nabi Muhammad sudah sempurna dan bersifat absolut, sehingga tidak perlu lagi ada perubahan? Padahal zaman selalu berubah, masalah yang dihadapi oleh generasi demi generasi selalu berkembang.

Dalam sejarah hukum Islam, istilah syariat hampir-hampir tidak pernah dipergunakan pada masa-masa awal Islam. Istilah ini diperkenalkan untuk pengertian khusus, yakni hukum Islam pada masa yang kemudian. Alquran juga menggunakan kata-kata shari'ah dan shir'ah dalam arti al-din (agama), dalam pengertian jalan yang jelas yang telah ditunjukkan Allah pada manusia, seperti dalam QS. al-

\footnotetext{
${ }^{37}$ Riḍa, Al-Manār, vol. 6, 342.

${ }^{38}$ Wahyu Ihsan, "Menyoal Agama Para Nabi dan Rasul Terdahulu, Antara Agama Islam dan Agama Tauhid," dalam Jurnal Bidayah, vol 8, no. 2 (2017), 173.

${ }^{39}$ Kementerian Agama, Tafsir Maudhu'i, vol. 9, 127.
} 
Mäidah [5]: 48 dan QS. al-Jāthiyah [45]: 18. Kata sharíab pernah digunakan pada masa rasul dengan arti pokok-pokok ajaran agama, yaitu ketika orang-orang Arab Badui meminta kepada rasul agar mengutus seseorang untuk mengajari sharaì' (jamak dari shari'ab). Abū Hanifah munggunakan kata shari'ah lebih sempit dari kata al-dìn. Dalam kitab Al-'Alim wa al-Muta'allim, dia membedakan kata al-din sebagai pokok-pokok keimanan yang dibawa para rasul yang tidak pernah berubah, sedang syariat sebagai kewajiban-kewajiban yang harus dijalankan, bisa berbeda antara rasul yang satu dengan lainnya. ${ }^{40}$

Kata shari $a h$ hingga abad kedua hijriyah masih dipakai untuk seluruh aspek ajaran agama, karya Abū Hanifah di atas menunjukkan hal itu, tidak hanya aspek hukum. Tahap berikutnya, arti shari'ah menyempit menjadi ajaran Islam yang berkaitan dengan masalah hukum. Apabila dihubungkan dengan kata figh, maka kata shari'ah mempunyai makna yang sama dengan fikih.

Allah meyempurnakan agama-agama yang dibawa oleh para nabi terdahulu dengan agama yang datang kemudian, yaitu agama Islam. Nabi Muhammad adalah pamungkas para nabi. Misi yang diembannya adalah untuk seluruh umat manusia. Berbeda dengan para nabi sebelumnya, misinya terbatas hanya untuk umat tertentu. Oleh karena itu syariatnya juga relatif terbatas oleh dimensi ruang dan waktu. Jadi di bidang akidah semua nabi dan rasul mengajarkan agama tauhid, tidak ada yang berbeda. Dalam persoalan akidah tidak mengenal evolosi. Sedangkan di bidang syariat (fikih) yang mengatur perilaku manusia baik dalam hubungan vertikal maupun horisontal, mengalami perkembangan sesuai dengan kontek zaman dan tempat. Dan syariat yang dibawa nabi Muhammad berlaku universal, karena lebih mengedepankan akal dan memberi ruang para mujtahid untuk berijtihad menemukenali hukum yang terkandung dalam Alquran dan Sunah.

\section{Misi Kenabian dan Kerasulan}

Kata misi merupakan kata pinjaman yang berasal dari bahasa Inggris missión yang semakna dengan kata task, duty, job, assignment dan lain-lainnya yang berati tugas atau pekerjaan. Dalam bahasa Arab

\footnotetext{
${ }^{40}$ Ahmad Hassan, The Early Development (Islamabad: Islamic Research Institute, 1970), 7-8.
} 
disebut wazifah bentuk jamaknya wază'if. ${ }^{41}$ Misi kenabian dan kerasulan secara umum sama yaitu tabligh atau menyampaikan pesan suci (wahyu) yang diterima nabi dan rasul pada umatnya. Sebagaimana disebutkan dalam QS. al-Mā'idah [5]: 65, adalah sebuah keniscayaan bagi semua utusan Allah untuk menyampaikan pesan yang diterimanya. Tidak ada nabi apalagi rasul yang mengabaikan misi yang diembannya. Tabligh merupakan komitmen sosial nabi dan rasul serta implementasi dari sifat amanah. 'A $\overline{l i}$ al-Ṣābūni menyebutkan secara detail misi kenabian sebagai berikut:

Pertama, tugas pertama dan utama seorang nabi adalah mengenalkan makhluk (manusia) pada Penciptanya, beriman pada keesaan-Nya dan beribadah hanya kepada-Nya, tidak kepada lainNya. Tugas ini disebutkan dalam QS. al-Anbiyā' [21]: 25 dan QS. alNahl [16]: 36. Kedua, menyampaikan perintah dan larangan (syariat) yang berlaku bagi umatnya, seperti dalam QS. al-Ahzāb [33]: 39. Ketiga, menunjukkan dan membimbing manusia ke arah jalan yang benar seperti dalam QS. 14 (Ibrähim): 5. Keempat, menjadi teladan bagi umatnya seperti dalam QS. al-Aḥzāb [33]: 21. Kelima, mengingatkan umatnya tentang asal-usul dan tempat kembalinya seperti dalam QS. al-An‘am [6]: 130-131. Keenam, memalingkan fokus perhatian manusia dari kehidupan yang sementara menuju kehidupan yang kekal, seperti dalam QS. al-'Ankabūt [29]: 64. Ketujuh, menjadi hujah bagi Allah, untuk megantisipasi klaim orang kafir diakhirat kelak, seperti dalam QS. al-Nisā' [4]: 165. ${ }^{42}$ Penyebutan misi nabi dan rasul di atas cukup banyak, menjabarkan konten tugas yang diemban para nabi, mencakup peran, strategi dakwah dan tujuan Allah dalam mengutus para nabi.

Tim penyusun Tafsir Maudbu'i Kementerian Agama Republik Indonesia menyebutkan bahwa tugas pokok para rasul dan nabi adalah "tabligh", yaitu menyampaikan wahyu yang diterimanya pada umat yang dipandunya. Rasul maupun nabi menyampaikan ajaran yang sama, mengajak umatnya untuk berakidah yang sama, yaitu mengesakan Tuhan, dan melaksanakan syariat yang dibawanya. Para ulama membagi tahapan proses tabligh menjadi tiga tahap, yaitu tilawah (pembacaan), tazkiyah (pembersihan), dan ta'tim (pembelajaran). Sebagaiamana yang terdapat dalam QS. al-Baqarah

${ }^{41}$ Hanz Wehr, A Dictionary, 1080.

${ }^{42} \mathrm{Al}$-Ṣabūni, Al-Nubunwah, 25-27. 
[2]: 129 dan 151, QS. Āli 'Imrān [3]: 164, dan QS. al-Jum'ah [62]): 2. Sedangkan fungsi (strategi dakwah) para rasul dan nabi dipilah menjadi dua, yaitu memberi tabshïr, menyampaikan kabar gembira pada pelaku kebaikan, dan indhär, menyampaikan peringatan atau ancaman pada pelaku keburukan. ${ }^{43}$

Para mufasir memberikan interpretasi terhadap ketiga proses tugas kerasulan dan kenabian tersebut sebagai berikut. Pertama, tilawwah atau membacakan wahyu yang diterimanya, yaitu membacakan ayat-ayat Allah yang telah diturunkan kepada mereka, agar menjadi pelajaran dan petunjuk bagi umat mereka. Konten ayatayat tersebut berupa pelajaran tentang keesaan Allah, adanya hari kebangkitan dan pembalasan, adanya pahala bagi orang yang beramal saleh dan siksaan bagi yang inkar, petunjuk ke jalan yang baik dan sebagainya. ${ }^{44}$ Interpretasi di atas lebih menekankkan pada muatan wahyu yang disampaikan, yaitu tentang akidah terutama tentang keesaan Allah, hari kebangkitan dan pembalasan. Hari yang disebut terakhir ini merupakan pertanggung jawaban terhadap semua amal yang diperbuatnya di dunia, atau konsekuensi dari pengamalan akidah dan syariat, bagi yang beriman dan beramal saleh akan mendapatkan kebahagiaan dan ditempatkan di surga, sedangkan yang ingkar dan beramal sebaliknya akan mendapatkan siksa di neraka.

Muhammad 'Abduh memperluas cakupan makna ayat-ayat yang dibacakan. Menurutnya, bukan hanya wahyu yang sudah ditulis dalam kitab kitab suci, tetapi juga ayat-ayat kawniyah yang terbentang di sekitar kita dan ayat 'aqliyah yang merupakan pemahaman yang mendalam terhadap wahyu yang dibacakan, sehingga keduanya dapat menjadi dasar pembenaran (tasdiq ) terhadap ke-Esa-an Allah, kenabian dan kerasulan para nabi dan rasul-Nya. ${ }^{45}$

Pembacaan wahyu ini merupakan proses awal yang ditempuh dalam penyampaian misi kerasulan (tabligh) para rasul. Bahkan secara ekplisit Ibn 'Áshür menyebutkan bahwa tahap awal dari tabligh nabi Muhammad adalah membacakan Alquran. ${ }^{46}$ Pertanyaannya

\footnotetext{
${ }^{43}$ Tim penyusun Tafsir Maudbu'i Kemenag menyebut fungsi nabi ada 2: sebagai Tabshir dan Indhär.

${ }^{44}$ Kementerian Agama R.I., Al-Qur'an dan Tafsirmya, vol. 1 (Jakarta: Lentera Abadi. 2010), 203.

45Riḍ̄a, Al-Manār, vl. 1, 388.

${ }^{46} \mathrm{Ibn}$ 'Āshūr, Al-Taḅrì, vol. 1, 723 dan vol. 28, 209.
} 
kemudian adalah mengapa tahap awal dalam proses penyampaian misinya para nabi menggunakan tilawwah? Hal ini menunjukkan bahwa poses transfer of knowledge pada waktu itu yang paling efektif adalah tradisi lisan, karena belum tersedianya alat tulis dan teknologi yang menggantikan fungsi pembacaan. Di samping kondisi umat nabinabi terdahulu yang relatif sederhana, terutama umat Muhammad yang ummi (buta tulis dan baca), seperti dalam QS. al-Jumu'ah [62]: 2, maka penyampaian wahyu Tuhan pada umat yang dibimbingnya dilakukan melalui pembacaan. Membacakan berkali-kali ayat-ayat yang dihafalnya dengan baik, sehingga mereka memahami dengan mendalam, menghafalnya dengan baik, kemudian menumbuhkan keimanan terhadap keesaan Allah dan kebenaran risalah yang diemban para rasul-Nya.

Kedua, tazkiyah (pembersihan), yaitu menyucikan diri dan jiwa umat yang dibimbingnya dari segala bentuk kesyirikan, kekufuran, kejahatan, budi pekerti yang tidak baik, sifat-sifat destruktif dalam masyarakat dan lain-lainnya. ${ }^{47}$ Para mufasir sepakat bahwa pembersihan yang dimaksud adalah menyucikan jiwa dari berbagai bentuk kekufuran dan syirik, di samping dari perbuatan keji dan akhlak yang tercela.

Ketiga, ta'lim (pembelajaran). Para nabi dan rasul mengajarkan wahyu yang diterima kepada umatnya, secara detail dan mendalam sehingga menemukan rahasia dan hikmah yang terkandung di dalamnya. Upaya memperbaiki dan membahagiakan umat, tidaklah cukup dengan pembelajaran yang bersifat akademik, tetapi harus disertai dengan mendidik dan membimbingnya agar senang mengerjakan perbuatan baik dan terpuji, memberikan motivasi untuk beramal saleh, peneladanan yang baik serta strategi yang tepat. ${ }^{48}$ Nabi Muhammad menerima wahyu yang terhimpun dalam kitab suci Alquran, maka dia mengajarkan al-kitäb dan al-hikmah, seperti tersebut dalam QS. al-Jum'ah [62]:2. Al-Kitāb yang dimaksud adalah Alquran, sedangkan al-bikmah adalah rahasia-rahasia dan faedah-faedah yang terdapat dalam Alquran. Mengajarkan hukumhukum syariat, tujuan diutusnya para rasul dan menjadi contoh yang baik bagi umatnya, sehingga mereka dapat menempuh jalan yang lurus. ${ }^{49}$

\footnotetext{
${ }^{47}$ Kementerian Agama, Al-Qur'an dan Tafsirnya, vol. 1, 203.

${ }^{48}$ Riḍā, Al-Manār, vol. 1, 389.

${ }^{49}$ Kementerian Agama, Al-Qur'an dan Tafsirnya, vol. 1, 203.
} 
Dalam penyampaian misi kenabian dan kerasulan, mereka tidak hanya memberikan pembelajaran yang bersifat kognitif, memahami dan mendalami wahyu yang diajarkan, tetapi mereka juga memperhatikan aspek psikomotorik dan afektif umatnya, sehingga tumbuh dalam jiwa umatnya kesadaran dan keinginan untuk mengimplementasikan wahyu, baik dari aspek akidah, syariat maupun akhlak.

Sedangkan fungsi (strategi dakwah) para nabi dan rasul adalah sebagai tabshir (menyampaikan kabar gembira) kepada pelaku kebaikan, indhar (menyampaikan peringatan atau ancaman) kepada pelaku keburukan, ${ }^{50}$ sebagaimana yang disebutkan dalam QS. alAhyzāb [33]: 45-46. Dengan menggunakan strategi dakwah di atas, maka para nabi dan rasul dalam menjalankan misinya tidak diperbolehkan menggunakan cara kekerasan dan pemaksaan, tetapi dengan cara yang elegan, bersifat informatif, dan mampu menyampaikan wahyu yang diterimanya dengan konsekuensi yang menyertainya. Bagi yang melaksanakan perintah dan meninggalkan larangan akan memperoleh kebahagian di dunia dan akhirat, sebaliknya bagi yang mengabaikan perintah dan melanggar larangan akan menderita di dunia dan akhirat.

\section{Kesimpulan}

Nabi adalah manusia biasa yang perlu makan, minum, nikah dan bergaul bersama umatnya, hanya saja ia mempunyai kelebihan, yaitu dipilih untuk menerima wahyu. Sebagai manusia pilihan, mereka bertanggungjawab untuk membumikan wahyu kepada umatnya. Baik nabi maupun rasul mempunyai komitmen sosial yang sama, membimbing umatnya untuk menggapai kehidupan yang bahagia dunia akhirat.

Sejak rasul dan nabi pertama hingga terakhir mempunyai risalah yang sama, mengajak umatnya untuk mengesakan Tuhan. Bedanya adalah terletak pada obyek atau materi wahyu yang diterimanya. Rasul membawa misi khusus pada umat baru (kafir atau musyrik) atau membawa syariat baru pada umat yang dibimbingnya. Sedangkan nabi adalah orang yang menjalankan tugas kenabiannya dalam kerangka wahyu atau syariat yang telah ada dan/atau pada umat yang lalai atau meninggalkan ajaran nabi sebelumnya.

\footnotetext{
${ }^{50}$ Kementerian Agama, Tafsir Maudhu'i, vol. 9, 127.
} 
Misi kerasulan dan kenabian relatif sama, yaitu bahwa tugas pokok para rasul dan nabi adalah "tabligh", yaitu menyampaikan wahyu yang diterimanya pada umat yang dipandunya. Mengesakan Allah, tidak menyekutukan dengan apapun, dan melaksanakan syariat yang dibawanya. Sedangkan tahapan proses tabligh yang ditempuh para rasul dan nabi adalah tilawah (pembacaan), tarkiyah (pembersihan) dan ta'tim (pembelajaran), dengan menggunakan strategi dakwah tabshï dan indhär.

\section{Daftar Pustaka}

'Āshūr (ibn), Muhammad al-Ṭăhir. Al-Taḥirir wa al-Tanwìr. Tunisia: alDār al-Tünisiyah li al-Nashr, 1984.

Alūsì (al), Shihāb al-Dīn al-Sayyid Maḥmūd. Rūḥ al-Ma'ānì. Beirut Dār al-Fikr, 1983.

Ash-Shiddieqy, TM. Hasbi. Sejarah dan Pengantar Ilmu al-Qur'an dan Tafsir. Semarang: Pustaka Rizki Putra, 2000.

Bāài (al), Muhammad Fu'ād 'Abd. Al-Mu'jam al-Mufahras li al-Alfā̌alQur'an al-Karim. Beirut:: Dār al-Fikr, 1987.

Badawi, Abdurrahman. Sejarah Ateis Islam, Penyelewengan, Penyimpangan, Kemapanan. terj. Khoiron Nahdiyyin. Yogyakarta: Lkis, 2003.

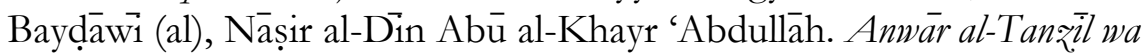
Asrār al-Ta'wīl. ed. Muhammad 'Abd al-Raḥmān al-Mur'ashili. Beirut: Dār Ihȳà' al-Turāth, t.th.

Hassan, Ahmad. The Early Development. Islamabad: Islamic Research Institute, 1970.

Hornby, A.S.. Oxford Advanced Learner's Dictionary of Current English. ed. Jonathan Crowther. Oxford: Oxford University Press, 1995.

Ihsan, Wahyu. "Menyoal Agama Para Nabi dan Rasul Terdahulu, Antara Agama Islam dan Agama Tauhid." Jurnal Bidayah, vol 8, no. 2 (2017).

Kathīr (ibn), Abū al-Fidā' Ismā̄īil. Tafsìr al-Qur'ān al-Ażim. Beirut: Dār al-Fikr, 1986.

Māwardì (al), Abū al-Ḥasan 'Alì b. Muḥammad b. Ḥabīb. Al-Nukat wa al-Uyūn. Beirut: Dār al-Kutub al-'Tlmìyah, t.th.

Manzur (ibn), Muhammad. Lisān al-'Arab al-Muhịt. Beirut: Dār lisān al-'Arab, t.th.

Marāghì (al), Aḥmad Muṣtafā. Tafsìr al-Marāghì. Beirut: Dār al-Fikr, t.th. 
Munawir. "Konsep Kenabian Menurut Ibnu Khaldun Telaah Korelasi Kemaksuman dan Kemanusiaan Nabi Muhammad SAW.." Jurnal Bidayah, Vol. 15, No. 1 (2014).

Munawwir, Ahmad Warson. Kamus al-Munawmir. Yogyakarta: PP. AlMunawwir, 1984.

Qurtubī (al), Abū 'Abdillāh Muḥammad b. Aḥmad al-Anșārì. Al-Jāmi' li Abkām al-Qur'àn. ed. 'Abdullāh b. 'Abd al-Muhsin al-Turki. Beirut: al-Risālah, 2006.

R.I., Kementerian Agama. Al-Qur'an dan Tafsirnya. Jakarta: Lentera Abadi. 2010. . Tafsir Mudhu'i: Tafsir al-Qur'an Tematik. Jakarta: Lentera Ilmu Makrifat, 2019.

Rāzi (al), Muhammad Fakhruddin b. Diyā' al-Dīn 'Umar. Tafsìr alFakbr Al-Rä̃i al-Musbtahar bi al-Tafsìr al-Kabir wa Mafätị alGhayb. Beirut: Dār al-Fikr, 2005.

Riḍā, Muhammad Rashìd. Tafsìr al-Manār. Beirut: Dār al-Ma'árif, t.th. Șäbūnì (al), Muhammad 'Ali. Al-Nubunwah wa al-Anbiya'.' Damaskus: Mu'assasat al-Ghazā̄i, 1985.

Shaltūt, Maḥmūd. Al-Islām 'Aqüdah wa Sharīah. Mesir: Dār al-Qalam, 1966.

Shihab, Muhammad Quraish. Tafsir al-Mishbah. Jakarta: Lentera Hati, 2012.

Suyūṭi (al), 'Abd al-Raḥmān Jalāl al-Dīn. Al-Durr al-Mantbūr fì Tafsìr alMa’thür. Beirut: Dār al-Fikr, 2011.

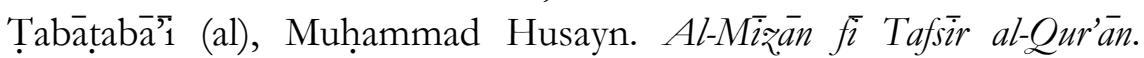
Beirut: Al-'Alami Library. t.th.

Tamimi (al), Muḥammad b. Hibbān. Sahịh b. Hịbān. Beirut: Mu'assasat al-Risālah, 1993.

Wehr, Hans. A Dictionary of Modern Written Arabic. Wiesbaden: Otto Harrassowitz, 1971.

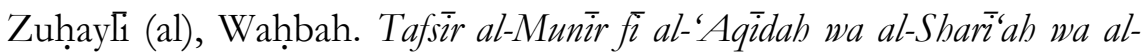
Manhaj. Beirut: Dār al-Fikr al-Mu'așirir, 1991.

Zulaiha, Eni. "Fenomena Nabi dan Kenabian Dalam Perspektif alQur'an." Al-Bayan Jurnal Studi al-Qur'a dan Tafsir, vol. 1, no. 2 (2016). 